\title{
STUDY OF THE GENETIC DIVERSITY OF MICROSYMBIONTS ISOLATED FROM Hedysarum gmelinii subsp. setigerum, GROWING IN THE BAIKAL LAKE REGION
}

\section{A.L. SAZANOVA, I.G. KUZNETSOVA, V.I. SAFRONOVA, A.A. BELIMOV, Zh.P. POPOVA, N.Yu. TIKHOMIROVA, Yu.S. OSLEDKIN}

All-Russian Research Institute for Agricultural Microbiology, Federal Agency of Scientific Organizations, 3, sh. Podbel'skogo, St. Petersburg, 196608 Russia, e-mail v.safronova@rambler.ru (corresponding author)

ORCID:

Sazanova A.L. orcid.org/0000-0003-0379-6975

Kuznetsova I.G. orcid.org/0000-0003-0260-7677

Safronova V.I. orcid.org/0000-0003-4510-1772

The authors declare no conflict of interests

Acknowledgements:

We thank A.V. Verkhozina (SIPPB SB RAS) for organizing the expedition to the Baikal Lake region.

Supported by the Federal Agency of Scientific Organizations (Program for the development and inventory of bioresource collections, № ISGZ 0664-2016-0018). ITS-sequencing of the isolates was supported by the Russian Science Foundation (grant 16-16-00080).

Received March 11, 2017

One of the urgent problems of modern microbiology and biotechnology is the study of the mechanisms of interaction between leguminous plants and root nodule bacteria (rhizobia), which are an extensive group of microorganisms capable to form nitrogen-fixing symbiosis with a host plant. Knowledge of these mechanisms is necessary for carrying out scientifically based selection of highly effective rhizobia-legume symbiotic systems. To understand the evolution of the specificity of plantmicrobe interactions, symbiotic systems with the participation of relic leguminous plants, which are an intermediate link between the extinct and modern species, are of particular importance. One of these unique objects is the pleistocene relict Hedysarum gmelinii Ledeb. subsp. setigerum (Turcz. ex Fischer et Mey.) Kurbatsky. The aim of this study was to isolate and identify the world's first collection of microsymbionts of this plant species growing in the Lake Baikal region. The study of taxonomic positions of 19 isolates from root nodules of $H$. gmelini subsp. setigerum plants was conducted by the methods of ITS-RFLP and 16S rRNA gene (rrs) sequencing. Phylogenetic analysis revealed the considerable genetic diversity among microsymbionts of the plant species studied. Fourteen rhizobial isolates belonged to 3 genera: Rhizobium (family Rhizobiaceae), Phyllobacterium (family Phyllobacteriaceae) and Bosea (family Bradyrhizobiaceae). It was noted the presence in the root nodules of non-symbiotic rhizobial species that are not able to form symbiosis with leguminous plants (Phyllobacterium endophyticum, Ph. loti and Bosea sp.). In addition, five non-rhizobial isolates belonging to the genera Acinetobacter, Stenotrophomonas, Sphingomonas and Agromyces were obtained. The obtained data may indicate that the relic rhizobia-legume symbioses, formed in particular by the $H$. gmelini subsp. setigerum plants, are prototypes of modern symbiotic systems and reflect the evolutionary pathways in the direction of recruiting symbiotic genes of different microorganisms and increasing the specificity of plant-microbe interactions. It is possible that strains of non-symbiotic rhizobial species are present in nodules as a source of genes that do not participate directly in the formation of symbiosis, but affect its activity. Such strains, after appropriate genetic and phenotypic study, can be used for the production of biopreparations with increased efficacy.

Keywords: leguminous plants of the Baikal region, Hedysarum gmelinii subsp. setigerum, ribosomal RNA genes sequences, Rhizobiaceae taxonomy

Rhizobia, a large genetically diverse group of Gram-negative soil microorganisms, are capable of establishing intracellular symbiosis with leguminous plants and performing fixation of atmospheric nitrogen by forming symbiotic nodules on the roots of host plants, due to which these microorganisms are also known as nodule bacteria. Scientific selection of highly effective plant-microbial systems necessitates understanding the molecular mechanisms that ensure the interaction of leguminous plants with rhizobia, so these studies are among most 
urgent in modern microbiology and biotechnology [1]. Symbiotic systems of relict leguminous plants, which are an intermediate link between extinct and existing species, are of particular importance for understanding evolution of specific plant-microbial interactions. These unique objects include the sweetvetch Hedysarum gmelinii Ledeb. subsp. setigerum (Turcz. ex Fischer et Mey.) Kurbatsky which grows in the Baikal region [2]. Botanical and geographical analysis showed the belonging of this species to Pleistocene petrophytic steppe relics of South Siberian origin [3, 4].

The evidence was reported that bacteria Pantoea agglomerans, Enterobacter kobei, Enterobacter cloacae, Leclercia adecarboxylata, Escherichia vulneris and Pseudomonas sp. (class Gammaproteobacteria) were isolated from the nodules of Hedysarum spinosissimum subsp. capitatum and some other species of this genus ( $H$. pallidum, H. carnosum) growing in the Mediterranean region [5]. H. coronarium is nodulated by Rhizobium sullae strains [6]. According to Chinese researchers [7], Rhizobium strains were isolated from the nodules of $H$. scoparium and $H$. polybotrys which grow in the Chinese northwest. In 2011, it was shown that the plants of the alpine sweet vetch $H$. alpinum are nodulated by representatives of Mesorhizobium genus [8].

The microsymbionts of the $H$. gmelinii Ledeb. subsp. setigerum have never been isolated before. In the present work, we have created and described the world's first collection of rhizobial microsymbionts of this relict leguminous plant growing in the Baikal region.

The purpose of our study was to isolate the Hedysarum gmelinii subsp. setigerum microsymbionts and determine the taxonomic position of the strains using the ITS-RFLP method and 16S rDNA sequencing.

Techniques. The objects of the study were 19 strains isolated using the traditional method [9] from the root nodules of $H$. gmelinii subsp. setigerum growing on the Zunduk Cape (mainland coast of the Baikal strait Maloye More, coordinates 53.383333, $107.41666753^{\circ} 23^{\prime} 00^{\prime \prime}$ N. $107^{\circ} 25^{\prime} 00^{\prime \prime}$ E). Microorganisms were grown on modified mannitol yeast agar YMSA with addition of $0.5 \%$ succinic acid [10] at $28^{\circ} \mathrm{C}$. All isolates are deposited in the Departmental Collection of Useful Agricultural Microorganisms and placed at the Station for LowTemperature Automated Storage of Biological Samples (Liconic Instruments, Liechtenstein) [11]. The information on the strains is available in the Internet database of the Russian Collection of Agricultural Microorganisms [12].

In the initial assessment of the intra-species diversity of strains, RFLP (restriction fragment length polymorphism) analysis of sequences between the genes $16 \mathrm{~S}$ and $23 \mathrm{~S}$ rRNA (ITS-RFLP method) was performed. For this, the amplified DNA fragment was cleaved with MspI restriction endonuclease (Promega, USA) and the restricted DNA fragments were separated electrophoretically in the standard mode [13]. For species identification of the strains, the nucleotide sequence of the 16S rRNA (rrs) gene was used.

For amplification of $800 \mathrm{bp}$ ITS region, the primers FGPS1490-72 (5'TGCGGCTGGATCCCCTCCTT-3') and FGPL-132 (5'-CCGGGTTTCCCCATTCGG-3') were used, for amplification of $16 \mathrm{~S}$ rDNA of about $1500 \mathrm{bp}$, the primers fD1 (5'-AGAGTTTGATCCTGGCTCAG-3') and rD1 (5'-AAGGAGGTGATCCAGCC-3') were used. The resultant PCR product was isolated from the gel and purified [14] for RFLP analysis or sequencing on a genetic analyzer ABI PRISM 3500xl (Applied Biosystems, USA). Detection of homologous sequences was performed using the NCBI GenBank database and the BLAST program [15]. A neighbor-joining tree was constructed by using the program MEGA5 [16] were used. Differences in the number of nucleotides which differed between the obtained sequences were revealed by a pairwise com- 
parison. To assess the levels of clusters support, a bootstrap analysis was performed based on 1000 replicates. The resulting sequences were deposited in the GenBank database (accession numbers KY290459-KY290467, KY290469, KY290470 and KY290472-KY290474).

Results. Isolates of nodule bacteria are presented in Tables 1 and 2.

1. 16S rRNA gene sequence homology $(\%)$ in fast-growing isolates from nodules of sweetvetch Hedysarum gmelinii subsp. setigerum (Baikal region) and type strains of Phyllobacterium and Rhizobium

\begin{tabular}{|c|c|c|c|c|c|c|c|c|c|c|c|}
\hline \multirow{3}{*}{$\begin{array}{l}\text { Type } \\
\text { strain }\end{array}$} & \multicolumn{11}{|c|}{ Isolate } \\
\hline & \multirow{2}{*}{$\begin{array}{c}\text { Rhizobium sp. } \\
\text { Hse- } 26\end{array}$} & \multicolumn{3}{|c|}{ Ph. loti } & \multicolumn{2}{|c|}{ Ph. endophyticum } & \multicolumn{5}{|c|}{ Phyllobacterium sp. } \\
\hline & & Hse-9 & Hse-19 & Hse-30 & Hse-10 & Hse-24 & Hse-13 & Hse-14 & Hse-17 & Hse-20 & Hse-29 \\
\hline 1 & 95.7 & 98.3 & 98.3 & 98.2 & 97.4 & 97.1 & 99.9 & 96.9 & 98.6 & 98.3 & 98.7 \\
\hline 2 & 94.5 & 99.6 & 99.6 & 99.5 & 97.9 & 97.7 & 99.6 & 97.4 & 98.9 & 99.7 & 98.9 \\
\hline 3 & 94.9 & 99.1 & 99.1 & 99.0 & 97.1 & 96.8 & 99.9 & 96.6 & 98.1 & 99.2 & 98.1 \\
\hline 4 & 94.6 & 98.6 & 98.6 & 98.6 & 96.6 & 97.1 & 99.2 & 96.1 & 97.7 & 98.6 & 97.7 \\
\hline 5 & 94.3 & 98.6 & 98.1 & 98.6 & 99.9 & 99.6 & 99.4 & 99.3 & 98.8 & 98.6 & 98.9 \\
\hline 6 & 95.1 & 98.5 & 98.6 & 98.4 & 98.5 & 98.2 & 99.6 & 98.0 & 99.3 & 98.6 & 99.3 \\
\hline 7 & 95.1 & 99.8 & 99.8 & 99.8 & 98.5 & 98.3 & 99.6 & 98.0 & 99.0 & 99.8 & 99.1 \\
\hline 8 & 98.9 & 94.4 & 94.4 & 94.3 & 93.5 & 93.3 & 95.0 & 93.1 & 94.8 & 94.4 & 94.8 \\
\hline 9 & 96.4 & 93.5 & 93.5 & 93.5 & 92.5 & 92.3 & 93.4 & 92.2 & 93.8 & 93.6 & 93.8 \\
\hline
\end{tabular}

2. 16S rRNA gene sequence homology (\%) in slow-growing isolates from nodules of sweetvetch Hedysarum gmelinii subsp. setigerum (Baikal region) and type Bosea strains

\begin{tabular}{l|c|c|c}
\hline \multicolumn{1}{c}{ Type strain } & \multicolumn{3}{c}{ Isolate Bosea sp. } \\
\cline { 2 - 4 } & Hse-21 & Hse-22 & Hse-32 \\
\hline B. vaviloviae Vaf-18T & 98,5 & 98,0 & 98,5 \\
B. massiliensis 63287T & 98,4 & 97,5 & 98,4 \\
B. eneae 34614T & 98,6 & 97,7 & 98,6 \\
B. vestrisii 34635T & 98,6 & 97,7 & 98,6 \\
\hline
\end{tabular}

All the studied isolates were divided into two groups based on the growth rate: three strains formed colonies on YMSA on days 4-5, and in the remaining strains, visible growth occurred on day 3 . Since each isolate generated a unique ITS-RFLP pattern (data not shown), all the strains studied were identified by rrs gene sequencing.

Sequence analysis showed that 11 fast-growing strains belong to the genera Phyllobacterium and Rhizobium and form 3 statistically reliably different clusters with a support level of $100 \%$ (Fig. 1). The first cluster included the strains Hse-14, Hse-24 and Hse-10, and also the type strain Ph. endophyticum PEPV15T. Hse-24 and Hse-10 strains which were identified as Ph. endophyticum showed high homology of rrs gene with that of the type strain PEPV15T (99.6\% and 99.9\%, respectively). The Hse-14 strain has been identified as Phyllobacterium sp. (Table 1). The second cluster combined the strains Hse-29, Hse-17, Hse-20, Hse-30, Hse-19, Hse-9, Hse-13 and the type strains Ph. sophorae CCBAU03422T, Ph. bourgognense STM201T, Ph. brassicacearum STM 196T, Ph. loti S658T, Ph. trifolii PETP02T, Ph. catacumbae CSC19T, Ph. myrsinacearum STM 948T and Ph. ifriqiyense STM 370T (Fig. 1). The Hse-20 strain was identified as Phyllobacterium sp., since being simultaneously the closest to two strains, Ph. trifolii PETP02T and Ph. loti S658T, by the $r$ s gene (the homology was $99.7 \%$ and $99.8 \%$, respectively). Similarity of rrs gene in the strains Hse-9, Hse-19 and Hse-30 and the type strain Ph. loti S658T reached $99.8 \%$. Hence, these strains were assigned to Ph. loti (see Table 1). The closest to the isolates Phyllobacterium sp. Hse-17 and Hse-29 was the type strain Ph. brassicacearum STM 196T (99.3\% homology of rrs gene). 


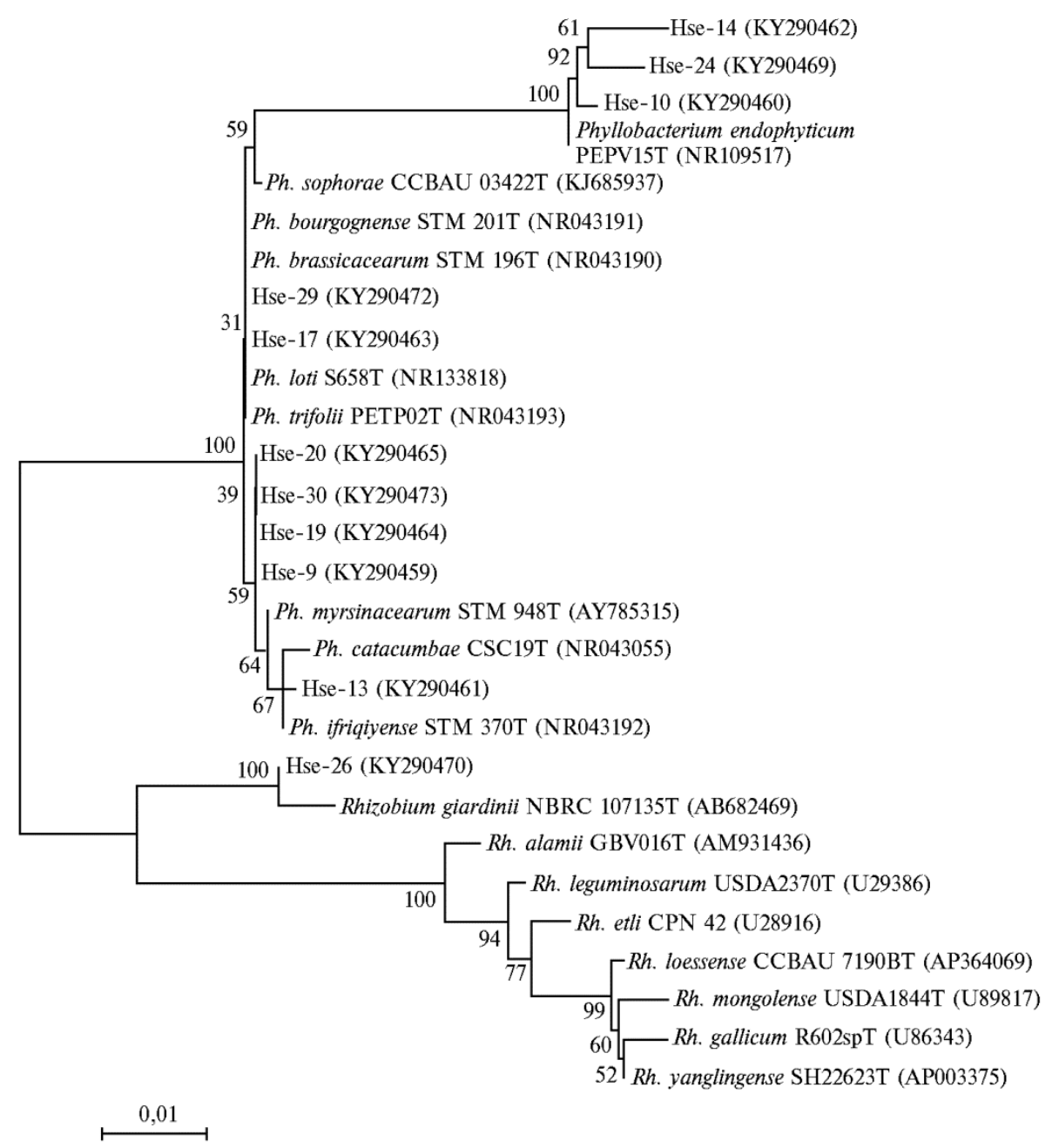

Fig. 1. rrs-Phylogram of the fast-growing strains isolated from nodules of sweetvetch Hedysarum gmelinii subsp. setigerum in Baikal region and the representatives of related species Phyllobacterium and Rhizobium. The obtained isolates are designated as Hse, type strains are marked with the letter "T".

The isolate Hse-13 and two type strains, Ph. myrsinacearum STM 948T and Ph. ifriqiyense STM 370T, showed $99.9 \%$ similarity; therefore, Hse-13 was identified only to the genus Phyllobacterium sp. (see Table 1). The third cluster was formed by the strain Hse-26 and the type strain Rhizobium giardinii NBRC 107135. Based on rrs gene sequencing (see Table 1), the Hse-26 isolate was identified as Rhizobium sp. with $98.9 \%$ similarity to the type strain Rhizobium giardinii NBRC 107135.

Fig. 2 shows the rrs-dendrogram reflecting the taxonomic position of three slow-growing rhizobial isolates within the Bradyrhizobiaceae genera. The strains Hse-21 and Hse-32 showed $98.5 \%$ rrs gene homology with the type strain Bosea vaviloviae Vaf-18T and $98.6 \%$ homology with the type strains $B$. eneae 34614T and B. vestrisii 34635T (see Table 2). The similarity of rrs genes in the Hse-22 isolate and the closest type strain vaviloviae Vaf-18T was $98.0 \%$ (see Table 2). On this basis, the strains Hse-21, Hse-22 and Hse-32 were identified as Bosea sp. It should be noted that B. vaviloviae was described quite recently, in 2015, when three microsymbiont strains were discovered in the relict legume plant Vavilovia formosa which grows in North Ossetia [10]. In addition, the microorganisms of the Bosea and Phyllobacterium genera were not isolated 


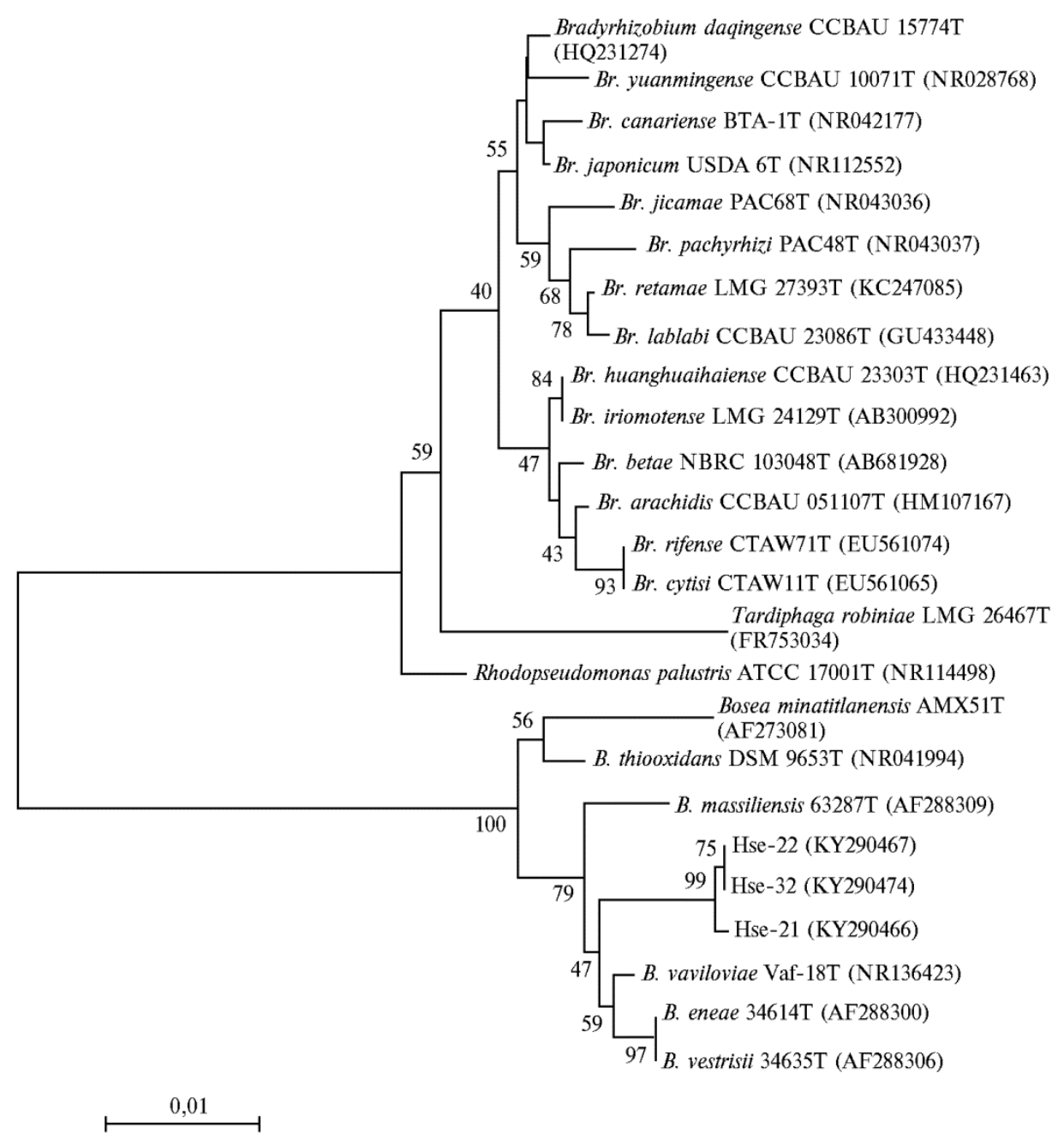

Fig. 2. rrs-Phylogram of the slow-growing strains isolated from nodules of sweetvetch Hedysarum gmelinii subsp. setigerum in Baikal region and the representatives of related species Bosea. The obtained isolates are designated as Hse, type strains are marked with the letter "T".

from the nodules of other sweetvetch species that grow in the Mediterranean, northwestern regions of China and central Russia [5-8].

The ability of any members of Bosea genera to form a nitrogen-fixing symbiosis has not been confirmed before, although strains of four species, $B$. lupi$n i, B$. lathyri, B. robiniae and B. vaviloviae, were isolated from the nodules of $\mathrm{Lu}$ pinus, Lathyrus, Robinia and Vavilovia leguminous plants, respectively [10, 17]. However, at least two Phyllobacterium species, Ph. sophorae and Ph. trifolii, were described as effective microsymbionts of Sophora flavescens [18], Trifolium repens and Lupinus albus [19]. Therefore Baikal isolates of Bosea genera, which show high similarity to B. vaviloviae species, and Phyllobacterium bacteria are of great interest for further study.

Based on rrs gene sequences, five non-rhizobial isolates from sweetvetch Hedysarum gmelinii subsp. setigerum nodules were attributed to genera Acinetobacter, Stenotrophomonas, Sphingomonas and Agromyces (data not shown). Bacteria of Stenotrophomonas genera were isolated from other leguminous plants of the Baikal region [20]. According to data reported, the members of these genera can inhabit the nodules of legumes and also the rhizosphere and phyllosphere of various plant species [21-25]. 
Thus, in the present paper, for the first time, we have obtained a collection of strains isolated from the relict leguminous plant, the sweetvetch Hedysarum gmelinii Ledeb. subsp. setigerum, which grows in the Baikal region. Our study showed that among the microsymbionts of this plant there are strains of symbiotic species of nodule bacteria (Rhizobium sp.), as well as atypical species, which representatives do not form symbiosis (Phyllobacterium endophyticum, Ph. loti and Bosea sp.). Strains of non-symbiotic rhizobial species may be present in nodules as carriers of genes that do not directly participate in the formation of symbiosis, but can affect its effectiveness. Further phenotypic and genetic study of isolated microorganisms can make a significant contribution to understanding the ways of evolution and development of plant-microbial interactions in the legume-rhizobial system.

\section{REFEREN CES}

1. Tikhonovich I.A., Borisov A.Yu., Tsyga nov V.E. Uspekhi sovremennoi biologii, 2005, 125(3): 227-238 (in Russ.).

2. Elektronnyi katalog sosudistykh rastenii Aziatskoi Rossii. Available http://wwwsbras.nsc.ru/win/elbib/atlas/flora/271.html. No date (in Russ.).

3. Muldashev A.A., G a le eva A.Kh., M a s lova N.V., Eli za r' e va O.A. Vestnik Orenburgskogo gosudarstvennogo universiteta, 2009, 6: 254-257 (in Russ.).

4. Kulik ov P.V. Konspekt flory Chelyabinskoi oblasti (sosudistye rasteniya) [Abstract of Chelyabinsk region flora]. Ekaterinburg, 2005 (in Russ.).

5. Benhizia Y., Benhizia H., Benguedouar A., Muresu R., Giacomini A., S quartini A. Gamma proteobacteria can nodulate legumes of the genus Hedysarum. Systematic and Applied Microbiology, 2004, 27(4): 462-468 (doi: 10.1078/0723202041438527).

6. Squartini A., Struffi P., Doring H., Selenska-Pobell S., Tola E., Giacomini A., Vendramin E., Velazquez E., Mateos P.F., MartínezMoli n a E., D a z z o F.B., C a s e 11 a S., $\mathrm{N}$ u t i M.P. Rhizobium sullae sp. nov. (formerly Rhizobium hedysari), the root-nodule microsymbiont of Hedysarum coronarium L. International Journal of Systematic and Evolutionary Microbiology, 2002, 52: 1267-1276 (doi: 10.1099/00207713-52-4-1267).

7. We i G.H, Zhang Z.X., Che n C., Che n W.M., J u W.T. Phenotypic and genetic diversity of rhizobia isolated from nodules of the legume genera Astragalus, Lespedeza and Hedysarum in northwestern China. Microbiological Research, 2008, 163(6): 651-662 (doi: 10.1016/j.micres.2006.09.005).

8. S a fronova V.I., Chizhevskaya E.P., B elimov A.A., Pavlova E.A. Taxonomy of microsymbionts of Hedysarum and Astragalus basing on ribosomal RNA genes sequencing. Sel'skokhozyaistvennaya biologiya [Agricultural Biology], 2011, 3: 61-64 (in Russ.).

9. Novikova N., S afro nova V. Transconjugants of Agrobacterium radiobacter harbouring sym genes of Rhizobium galegae can form an effective symbiosis with Medicago sativa. FEMS Microbiology Letters, 1992, 93: 261-268 (doi: 10.1016/0378-1097(92)90472-Z).

10. Safronova V.I., Kuznetsova I.G., Sazanova A.L., K imeklis A.K., B e limov A.A., Andronov E.E., Pinaev A.G., Chizhevskaya E.P., Pukhaev A.R., Popov K.P., Wille ms A., Tikhonovi ch I.A. Bosea vaviloviae sp. nov., a new species of slow-growing rhizobia isolated from nodules of the relict species Vavilovia formosa (Stev.) Fed. Antonie van Leeuwenhoek, 2015, 107: 911-920 (doi: 10.1007/s10482-015-0383-9).

11. Safronova V., Tikhonovi ch I. Automated cryobank of microorganisms: Unique possibilities for long-term authorized depositing of commercial microbial strains. In: Microbes in applied research: current advances and challenges. A. Mendez-Vilas (ed.). World Scientific Publishing Co, Hackensack, 2012.

12. Elektronnaya baza dannykh Vedomstvennoi kollektsii poleznykh mikroorganizmov sel'skokhozyaistvennogo naznacheniya (VKSM). [online Database of The Russian Collection of Agricultural Microorganisms (RCAM)]. Available http://www.arriam.spb.ru. No date (in Russ.).

13. Rumyants eva M.L., Si marov B.V., O $\mathrm{n}$ is h c hu k O.P. Biologicheskoe raznoobrazie kluben'kovykh bakterii $v$ ekosistemakh $i$ agrotsenozakh. Teoreticheskie osnovy $i$ metody /Pod redaktsiei M.L. Rumyantsevoi, B.V. Simarova [Biodiversity of nodulating bacteria in ecosystems and agrocoenoses. Theoretial aspects and methodology. M.L. Rumyantseva, B.V. Simarov (eds.)]. St. Petersburg, 2011 (in Russ.).

14. Stępkowski T., Żak M., Moulin L., Kryliczak J., Golińska B., Narożn a D., S a fro nova V.I., Mąd rzak C.J. Bradyrhizobium canariense and Bradyrhizobium japonicum are the two dominant rhizobium species in root nodules of lupin and serradella plants 
growing in Europe. Systematic and Applied Microbiology, 2011, 34: 368-375 (doi: 10.1016/j.syapm.2011.03.002).

15. GenBank sequence database. The National Center for Biotechnology Information. Available https://blast.ncbi.nlm.nih.gov/Blast.cgi. No date.

16. Tamura K., Peterson D., Peterson N., Stecher G., Nei M., Kumar S. MEGA5: Molecular evolutionary genetics analysis using Maximum Likelihood, evolutionary distance, and Maximum Parismony methods. Molecular Biology and Evolution, 2011, 28: 2731-2739 (doi: 10.1093/molbev/msr121).

17. D e Me ye r S.E., Wille m s A. Multilocus sequence analysis of Bosea species and description of Bosea lupini sp. nov., Bosea lathyri sp. nov. and Bosea robiniae sp. nov., isolated from legumes. International Journal of Systematic and Evolutionary Microbiology, 2012, 62: 2505-2510 (doi: 10.1099/ijs.0.035477-0).

18. J i a o Y.S., Yan H., Ji Z.J., Liu Y.H., Sui X.H., Zhang X.X., Wang E.T., $\mathrm{C}$ h e $\mathrm{n}$ W.X., $\mathrm{C}$ h e n W.F. Phyllobacterium sophorae sp. nov., a symbiotic bacterium isolated from root nodules of Sophora flavescens. International Journal of Systematic and Evolutionary Microbiology, 2015, 65: 399-406 (doi: 10.1099/ijs.0.067017-0).

19. Valverde A., Velázquez E., Fernández-Santos F., Vizcaíno N., Riva s R., Mateos P.F., Martíne z-Molina E., Ig u al J.M., Wille ms A. Phyllobacterium trifolii sp. nov., nodulating Trifolium and Lupinus in Spanish soils. International Journal of Systematic and Evolutionary Microbiology, 2005, 55: 1985-1989 (doi: 10.1099/ijs.0.63551-0).

20. Kuznetsova I.G., S a zanova A.L., S a fronova V.I., Tikhomirova N.Yu., O sle d ki n Yu.S., B eli m o v A.A. Genetic diversity among microsymbionts of Lathyrus, Vicia, Oxytropis and Astragalus legume species from Baikal region. Sel'skokhozyaistvennaya biologiya [Agricultural Biology], 2015, 50: 345-352 (doi: 10.15389/agrobiology.2015.3.345eng).

21. Cardoso J.D., Hungria M., Andrade D.S. Polyphasic approach for the characterization of rhizobial symbionts effective in fixing N2 with common bean (Phaseolus vulgaris L.). Applied Microbiology and Biotechnology, 2012, 93: 2035-2049 (doi: 10.1093/femsec/fix027).

22. Fterich A., Mahdhi M., Caviedes M.A., Pajuelo E., Rivas R., Rodri$\mathrm{gu}$ e z-L lo re nte I.D., M a rs M. Characterization of root-nodulating bacteria associated to Prosopis farcta growing in the arid regions of Tunisia. Archives of Microbiology, 2011, 193(6): 385-397 (doi: 10.1007/s00203-011-0683-z).

23. Ezzakkioui F., El Mourabit N., Chahboune R., Castellano-Hinojo s a A., B e d mar E.J., B a r rijal S. Phenotypic and genetic characterization of rhizobia isolated from Hedysarum flexuosum in Northwest region of Morocco. Systematic and Applied Microbiology, 2014, 37(6): 457-465 (doi: 10.1016/j.syapm.2014.05.009).

24. X u L., Z hang Y., W ang L., Che n W., We i G. Diversity of endophytic bacteria associated with nodules of two indigenous legumes at different altitudes of the Qilian Mountains in China. Journal of Basic Microbiology, 2015, 55(7): 830-837 (doi: 10.1002/jobm.201400790).

25. Corretto E., Antonielli L., Sessitsch A., Compant S., Gorfer M., Kuffn e r M., B rade r G. Agromyces aureus sp. nov., isolated from the rhizosphere of Salix caprea L. grown in a heavy-metal-contaminated soil. International Journal of Systematic and Evolutionary Microbiology, 2016, 66(9): 3749-3754 (doi: 10.1099/ijsem.0.001260). 